\title{
HEALTH IMPACT OF DOMESTIC VIOLENCE CASES DURING COVID-19 PANDEMIC: THE CASE STUDY IN MALANG REGENCY OF EAST JAVA
}

\author{
Suryani* and Atik Triratnawati** \\ * Student of Master of Anthropology, Faculty of Cultural Sciences, Gadjah Mada University \\ ** Lecturer of Anthropology Department, Faculty of Cultural Sciences, Gadjah Mada University \\ Suryani.psa@mail.ugm.ac.id
}

Keywords: Covid-19, Domestic Violence, Women's Health.

Abstract : The impact of Covid-19 has not only affected the health sector but also economic and social sectors. In the social sector, the increase of domestic violence cases is being concerned. It has a wide impact towards women's health. This paper wants to reveal the impact of women's health including reproductive health suffered by domestic violence victims and how they find solutions to the problems they face. Data collection was using ethnographic research methods from April to June 2021 in Malang regency. Observations and interviews were conducted towards 5 domestic violence victims and 2 associate staffs. Data analysis was carried out by classifying the data with the classification of minor, severe and reproductive health impacts. As a result, researcher found that domestic violence victims suffer health impact both physically and psychologically. Physically, they are experiencing bruises, swelling, up to stitches on the part of their body. While psychologically, they feel common to deep fear, cannot sleep well, feel insecure to experience trauma. As the impact of reproductive health, the victim suffered miscarriage. In conclusion, the victims are needed assistance to be brave enough to speak up and seek protection quickly and accurately.

\section{INTRODUCTION}

Pandemic Covid-19 has spread around the world since the end of 2019. The increasing number of cases has prompted Indonesian government to issue new policies to deal with this pandemic. One of the policies is Pembatasan Sosial Berskala Besar (PSBB). Yet, the "normal" risks of domestic violence, outside of a public health crisis, mean that the home is not a safe place for many women (UN Women et al., 2020: 19 in Krishnada $\&$ Taha, 2020: 49). There are many women in the world including in Indonesia experience more violence during their activities at home due to Covid-19. According to a report from Women's Commission, the number of domestic violence cases has increased during Covid-19 pandemic. In Malang Regency, there have been 9 domestic violence cases reported at the Dinas Pemberdayaan Perempuan dan Perlindungan Anak (DP3A) Kabupaten malang and 58 cases reported at Unit Perlindungan Perempuan dan Anak (UPPA) Polres Malang during 2020 (recorded since the presence of Covid-19 in March 2020).

It is undeniable that Covid-19 pandemic has also affected the society's socio-economic conditions. The appeal to stay at home has defeated the workers especially those who work in the field such as street vendors, peddlers, parking attendants and others, which most of them are in poor conditions. The decrease of income is also affected the poverty level in Malang Regency. On the other hand, many employees are also affected by the reduction of working hours. This more or less also affects the income they have (BPS Kab. Malang, 2020: 4-5).

Furthermore, study of domestic violence in Malang Regency did by Nadia focused on fulfilling the rights of domestic violence victims conducted by Pusat pelayanan Terpadu Pemberdayaan Perempuan dan Anak (P2TP2A) Kabupaten Malang. She found that the victims who sought assistance from P2TP2A were provided with assistance from the police, prosecutors, and courts but they did not receive the assistance of an advocate (Nadia, 2018). Meanwhile, the courage of the victim is the main key to whether or not the case is resolved. It is because many of the victims finally surrender and withdraw their reports after they have managed their emotions or after mediating with the perpetrators. In some cases, there was even a repetition of violence so that the victims report the incident once again.

In this study, researcher focuses on the impact of Covid-19 on domestic violence that occurred in Malang Regency and examines more deeply about the health impacts experienced by the victims during Covid-19 period. The health impacts are often ignored, whereas if we look at it, we have to pay attention to because it can threaten the lives of the victims. Many of them feel scared to the point of trauma after experiencing violence and they also suffered physical injuries due to the perpetrator's actions. Therefore, in this study, researcher tries to reveal the experiences of the victims because they often hide the violence against them on the grounds to maintain the 
integrity of their household. Moreover, the reasons why a wife does not report the violence committed by her husband is that the wife thinks that the husband's beating against them is not a legal problem, the report is considered shameful, where they are considered flawed in the eyes of the public if they report it, they are afraid of their husband's retribution, the wife is dependent economically and socially to the husband (Hadiati, 2001: 86).

The culture of the victims keep silent become a common thing for Indonesian people especially Javanese people. Brenner in his study of Javanese's ideology said that, "Javanese women give approval to the ideology that prioritizes the potential and status of men by supporting their husbands both in the public and private spheres by helping them avoid situations that might harm the prestige or dignity of their husbands" (Brenner, 1995: 41). This also happens when there is a problem in their household. Women prefer to remain silent and hide things that are considered a disgrace to their family. Violence against women occurs because of the culture of men domination over women. Violence is used by men to win dissent, express feelings of dissatisfaction, and often just to show that men have more power over women (Dewi in Scribd.com). The wife keeps the problem to herself, does not know how to solve it and is increasingly convinced of the wrong assumption, the husband is dominant over the wife. The household is the smallest and most autonomous social institution, so that it becomes a closed domestic area from the reach of public power (Aris, 2021: 20).

Meanwhile, according to Walker, domestic violence has 3 phases namely tension- building, acute battering and loving-contrition. The first is tension-building, which is the phase where the victim will experience a sense of fear and danger from the violence, often quarrels and physical violence begins. Second is acute battering which is the acute level of violence experienced by the victim, physical violence is becoming more frequent and if the condition does not subside or if the second phase does not reach the third phase, the danger of death will threaten the victim. The last is loving-contrition, in this phase the perpetrator of violence will usually apologize, promises not to repeat or even shower the victim with gifts so that the victim can trust the perpetrator again (Walker, 2009: 91).

The impact of violence against women usually causes physical pain, mental stress, decreased selfconfidence and self-esteem, feeling helpless, being dependence on their husbands who have abused them, experiencing post-traumatic stress, depression, and the desire to commit suicide (Hotifah, 2011: 65-66). Therefore, with this study, the researcher hoped that domestic violence victims especially those in Malang Regency can immediately get help both medically and legally. Come from this point, the researcher wants to examine several issues that are: why domestic violence increased during Covid-19 pandemic and how the impact of domestic violence on health including reproduction and the efforts of the victims to find solutions.

\section{RESEARCH METHOD}

In this study, the author uses an ethnographic research method with a research focus on domestic violence victims in the relationship between husband and wife in Malang Regency by taking the data reported in UPPA-Polres malang. This research conducted from April to June 2021.

In this qualitative research, the researcher obtained informants based on the willingness of the domestic violence victims to become the informants of this study. In addition, the five informants were selected based on variations in family backgrounds and regions that are Singosari, Lawang, Ngajum, Tajinan and Wagir Districts. These five districts also have different economic condition with Lawang and Singosari Districts being urban industrial areas where the majority of the society's livelihood is as factory employees, while Tajinan and Ngajum District are rural areas with the majority of the society's livelihood being farmers, and Wagir District which is the district borders with the city, so that the livelihood of the residents vary from farmers to factory employees.

Interviews with the victims were conducted to find out more detail the chronology of the incidents and the background of the victims and the perpetrators. This is important to know considering the society in Malang regency is very diverse. From this diversity, the author seeks to find out whether there are elements of differences factors that occurs the violence. In addition, the author also conducted a discussion with the staff who handled domestic violence cases at UPPA- Polres Malang. The result of the discussion is combined with the data obtained from the informants. From the data has been collected, the author conducted a literature review to validate the data that has been obtained.

\section{RESULTS AND DISCUSSIONS}

\section{The Cause of Domestic Violence in Malang Regency}

From the data obtained by the author through interviews with the informants, it can be found that some of the causes of domestic violence in Malang Regency are:

1) The first case with the code Pol-001. The victim has a background as a housewife with a side job making fried food which is sold in stalls. While the perpetrator is 52 years old, he has a Junior High School as his educational background and his job is buying and selling second-hand motorcycles. Their 
marital status is a husband and a wife. The violence occurs because her husband is jealous when she often plays her cellphones. The victim was trampled on until his feet swelled up during the argument, and she was threatened with shamanism to make her went mad, make her sick, and he would make her genitals be rotten if she dared to leave him. She is also not allowed to leave the house without her husband during their marriage. As a solution, she fled to her child's house which is outside the city and her child was directed her to report the incident to the police station. During the interview, she stated that she wanted to divorce her husband because she was afraid that the violence would happen again if the marriage still maintained. However, when the researcher conducted a discussion with the staff of UPPA-Polres Malang, it was found that the informant asked to suspend the investigation process against the perpetrator.

2) The second case with the code Pol-002. The victim is a housewife with the perpetrator who is 41 years old has an elementary school education background and has a job as a duck breeder. The current marital status of the victim and the perpetrator is husband and wife with the victim as the second wife (polygamy). The problem occurs when the victim feels that the first wife gets more attention from her husband by buying the first wife jewelry. A fight occurred and made the perpetrator angry with the victim's accusation so that the perpetrator beat, kicked and slapped her until her temple was bruised. She then reported the case to the local village apparatus, who was then accompanied by the local head of Citizens Association (RW) to report the incident to the police station. In this case, she was able to resolve the problem by making peace with the perpetrator after mediation was carried out by the village apparatus along with the local head of Neighborhood Association (RT) and head of Citizens Association (RW) and then the report at the UPPA-Polres Malang was withdrawn.

3 ) The third case with the code Pol-003. The victim has a background as a street vendor while the perpetrator is a security guard at a factory who is 30 years old with a high school education background. The marital status of the victim with the perpetrator is currently husband and wife. The incidents of violence occur when the perpetrator asks for money by force to the victim. She intends to hold the money taken by the perpetrator because the money is fund to buy goods for her sale. When they are snatching the bag that contain money, she was pushed to the ground by her husband causing wound on the head, bruises on the right cheek and right hand. In addition, the perpetrator also often committed sexual violence by forcing her to have sex with him. He also often threatens to kill her and curse her with dirty words. She immediately reported the incident to UPPA-Polres Malang after previously reported similar violence incident committed by him. She said that she wanted to file a divorce as a solution to the problem so that the violence incidents would not happen again.

4) The fourth case with the code Pol-004. The background of the victim is a cigarette factory employee while her husband is a farmer who is 33 years old with a junior high school education background. The marital status of the victim and the perpetrator is currently husband and wife. The violence occurred because the perpetrator ordered her to prepare food for him, but she had just returned from work she was still tired and did not immediately make the food requested by him. He was angry and hit her head with a broom until her head suffered stitches. After committing the physical violence, he threatened to kill her by using a sickle if she dared to leave the house. But, she was successfully escaping from the house, she was looking for help at her brother's house then her brother escorted her to the nearest police station. The solution to this problem is to arrest the perpetrator after the victim reports the case, and the victim is in the process of filing for divorce to the Religious Court.

5) The fifth case with the code Pol-005. The victim is a factory worker whose husband is a 50 years old contractor project worker with an educational background of junior high school. The perpetrator often neglects the victim by going with other women and not coming home for several months. When he comes home, he has lost his job so the victim must meet all of his needs. After getting back to work, he went back with another woman and rarely came home. It was made the victim emotional and took the initiative to make him jealous by posting a random photo of a man she took from a social media. The perpetrator felt jealous and went home by carrying a machete and then dragged the victim into the street to find the house of the man whose photo was posted by her. After she managed to escape from the perpetrator, she ran to a neighbor's house which to ask for help, and then he fled. In this case, the victim immediately filed for divorce, so the current marital status they were divorced.

From the data above, it can be seen that the economic condition of the perpetrators on average is a weak and low educational background. This is very influential during Covid-19 pandemic because the economic condition is shaken. Many companies are closed so it has an impact on their income including those who make a living as farmers who could not sale the harvest outside their area. This is where their emotional state begins difficult to control, and mostly vent their anger on the families, especially their wives.

As for the victims, 2 of the 5 informants are housewives whose income depends on their husbands, while the other 3 have personal income 
from their own business or from their work as a factory worker. One of the two informants has suspended the investigation while the other one has withdrawn the report and reconciled with the perpetrator after mediating. The other three victims who have their own jobs are still trying to solve the case, and one of them has filed divorce from the perpetrator. The result of the analysis that we can see is the independence women in terms of work have a greatly influence for the process of whether or not the report continues. It is because the economic dependence of a wife towards her husband make a weaken position for them and easily forgive the perpetrator.

\section{Domestic Violence Cases Increasing during Covid-19 Pandemic}

From the data report of UPPA-Polres Malang, it can be seen that there has been a spike in domestic violence cases since Covid-19 being announced in Indonesia in March 2020 by recording 8 cases specifically of husband-wife relations. This coincides with the start of the government's policy of studying from home for all students in Indonesia. Meanwhile, in the previous month, in January and February 2020, there were 4 and 3 domestic violence cases respectively. Furthermore, coincide with the Large-Scale Social Restrictions (PSBB) in Malang Raya (Malang Regency, Malang city and Batu city) in May 2020, the cases of domestic violence reported at UPPAPolres Malang has another increased with 10 cases.

From the data above, it can be seen that the increase number is quite high, even 2 times from the previous months (before Covid-19 outbreak). The results of the discussion between the researcher and UPPA-Polres Malang staffs explained that the direct factor of domestic violence was not due to Covid-19, but the incidence of violence on average was dominated by economic problems and third persons. Domestic violence might not directly affected by Covid-19, but indirectly it occurs because of the declining economic factor of the society, both for those who have lost their jobs, reduced sales, or those who cannot sell their crops outside their area due to Large-Scale Social Restrictions (PSBB). And with high levels of stress due to declining income, it is easy to get emotional for anyone considering that the wishes to return to normal conditions are still uncertain. With this condition, people are easy using their family to vent their anger.

\section{Health Impact on Domestic Violence Victims}

From the data has been collected, it can be seen that domestic violence victims are experiencing fear, sleep disturbances, feeling insecurity, cannot concentrate, lose self-confidence and feel traumatized after the incident. With this condition, it can be said that the victim has a mental health disorder. Here, the researcher categorizes the health impacts of domestic violence victims into 2 that are minor and severe health impacts. Minor health impacts consist of bruising, lacerations and swelling on her body. Psychologically, they often worried about the incident happening again, the usual fear, and cannot sleep. While the serious health impacts include leaking wounds (bleeding) on certain body parts, torn wounds that require stitches, broken bones, the victim is experience disabled, until the risk of dying. And psychologically, they experienced excessive fear, trauma, depression to mental disorders, and attempted suicide. As for other health impact is the reproductive health that in this study the victim suffered a miscarriage at 7 weeks of pregnancy.

One of the informants recounted her fear after running away from home after experiencing violence that caused injuries on her head. She said she was afraid that her husband came to her brother's house so she hid under the bed whenever a motorcyclist stopped.

"He was looking for me carrying out a sharp weapon.. So I am scared, until my sister-in-law is also scared to see me like that. She says, "don't be like that, you'll get stressed", but I feel scared every time a motorbike stops, so I hide under the bed" (case 4).

From the victim's statement, we can find out that the victim suffered fear and deep trauma after experiencing violence by her husband. She also explained when she left the house to go to police station, she wore a raincoat to cover up her body even though it was not raining, she hopes that her husband would not notice her because she was afraid that he was spying on her. The fear she experienced lasted for a quite time and finally she moved to his parents' house which was out of the town for several months at a time to have her condition checked by a psychologist.

The victims also experienced physical health problems. One of which was a victim who suffered a laceration on the head after being hit with a broom by her husband. The wound was finally treated by the hospital and stitches were done. The other victim suffered bruising in her temple and her back as a result of being pushed by her husband until she was thrown into a cupboard.

"My father thought he was only delivering my cellphone.. But he got angry and hit me.. I was hit and kicked, then slapped, and in this (temple) it was really bad yesterday, even now it still feels a little (the effect of being hit)" (case 2).

However, despite experiencing such violence, she decided to withdraw her report at the Polres Malang after mediating with her husband who was mediated by her family and local village officers. 
In addition to the psychological and physical health impacts, there are also reproductive health impacts that cause the victim a miscarriage after experiencing violence from her husband.

“.. I was just married for 4 months. I already experienced violence, at that time I was 7 weeks pregnant, until I miscarried.. It was when I caught him cheating on me with another woman" (case 5).

At that time of the incident, the victim did not report the incident of violence she was experienced, she did not even seek for help from her closest. She felt that there was something unusual with her stomach after experiencing the violence, so she went to the hospital to have her pregnancy checked, and there she was declared a miscarriage and needed medical attention. Even when medically treated, she did not say that she was experienced domestic violence that caused her miscarriage.

This culture of silence is a form of what Brenner has theorized about the Javanese ideology which adheres to belief that a wife must obey her husband, a wife must maintain the dignity of her husband and do not cause disgrace that can bring down her husband's dignity. Meanwhile, in the society domestic violence is considered as a family disgrace that must be kept confidentially. These cases need more attention, the health impact for the victim can result in severe depression and disrupt the mental health of the victim if they did not immediately get help from the medical institute. In addition, physical violence that lasts a long time can also cause disability in body parts or even death threat. As for reproductive health, if they did not get treatment immediately, it can also result in the loss of the mother's life in the case of miscarriage. While in the case of the perpetrator frequently changing partners (cheating with other women) the danger of transmitting sexually transmitted diseases can also be transmitted by the perpetrator to the victim, one of which is HIV/AIDS.

\section{The Lateness of Domestic Violence Victims in Seeking Help}

There are several reasons caused the victims do not immediately seeking for help after experiencing domestic violence. One of them that often told is because the victim does not have an access to leave the house after experiencing the violence. In addition, the perpetrator usually threatens the victim after physical violence occurs. Some were threatened with death if she dared to leave the house, some were threatened to be driven insane by means of supernatural powers, made her sick and make her genitals rot.

On the other hand, victims also think about society stigma related to their family issues that can be exposed when they report the violence. One of the informants even said that she hid the incidents she experienced from her own family. When her family asked about the bruises on her body, she made an excuse if she fell in her house or fell while riding a motorcycle.

"The first time I was hit, I never told my family, I kept it covered up, but in the end.. after getting married for 2 years, I couldn't stand it anymore, I finally told the story. Then I was asked, "it means when you often come here with bruises on your body were because beaten by him?", and I answered yes" (case 4).

She did this thing was to protect the name of her family especially the name of her husband in the eyes of her family. With the case like this, it is clear how the Javanese ideology that praises the dignity of men is more important than the victim own safety as a wife. And this culture has also been ingrained in the society of Malang Regency.

\section{CONCLUSION}

Domestic violence cases in Malang Regency revealed that the violence is still becomes a family secret that the victims are reluctant to seek help from outsiders when they experience domestic violence. The victims experienced the violence not only once or twice, but it happened many times before they could finally report the incident to UPPA-Polres Malang or to a smaller local institution such as RT, RW and local police. This violence has been carried out by the perpetrator against the victim for a long time even for years, so it has an impact on the health condition of the victims.

The health impacts experienced by the victims ranged from minor injuries in the form of bruising, neck pain, swelling in the legs, ordinary fear, feeling insecure, as well as severe health effects in the form of stitches on the head, deep fear, even trauma. Meanwhile, the impact related to reproductive health is that the victim suffered a miscarriage or has the potential to be infected a sexual disease due to the perpetrator changing partners. The impact on reproductive health is urgent to be addressed, considering that disturbed reproductive health will be dangerous for both mother and the baby.

In addition, threats of violence can also occur to other family members such as their children who live in the same house with them. The trauma experienced after seeing the violence that occurred in the family will hinder the growth of the child especially if the child is the only witness who will be involved in the victim's report. Therefore, it is necessary to have a solid synergy from various parties to handle domestic violence cases in Malang Regency considering the diverse society with diverse economic conditions as well. And the researchers hope that government agencies and future researchers can find ways to educate the society so they have the courage to speak up when 
they experience violence and to be able to detect violence early. By opening a domestic violence case, it will create a deterrent effect on the perpetrators so as to minimize the occurrence of ongoing violence.

\section{REFERENCES}

Amon, J. J. \& Wurth, M. (2020). "A Virtual Roundtable on Covid-19 and Human Rightswith Human Rights Watch Researchers". Health and Human Rights. Vol. 22, No. 1.

Aris. (2012). Identifikasi Kekerasan Dalam Rumah Tangga (KDRT): Studi pada Ibu Rumah Tangga di Desa Sumberrejo Kecamatan Gedangan Kabupaten Malang. Malang: Universitas Muhammadiyah Malang.

Badan Pusat Statistik Kabupaten Malang. (2020). Porfil Kemiskinan di Kabupaten Malang, Maret 2020. Malang: Badan Pusat Statistik Kabupaten Malang.

Brenner, S. (1995). "Why Women Rule the Roost: Rethinking Javanese Ideologies of Gender and Self-Control" dalam Bewitching Women, Pious Men: Gender and Body Politics in Southeast Asia. Aihwa Ong and Michael G. Peletz (peny). London: University of California Press, Ltd.

Data KDRT Unit PPA Polres Malang di Kabupaten Malang Tahun 2020. 2020. Malang: Unit Perlindungan Perempuan dan Anak Kepolisian Resort Kabupaten Malang.

Data KDRT di Kabupaten Malang Tahun 2021. 2021. Malang: Unit Perlindungan Perempuan dan Anak Kepolisian Resort Kabupaten Malang.

Dewi, N. R. "Kekerasan Dalam Rumah Tangga".

Dalam https://id.scribd.com/document/34780964 6/Kekerasan-dalam-rumah-tangga-doc Diakses pada tanggal 17 Mei 2021 pukul.

10.14 WIB.

Dinas Pemberdayaan Perempuan dan Perlindungan Anak (DP3A) Kabupaten Malang (2020). Data Statistik Aplikasi Wadool DP3A Kabupaten Malang. Malang: Dinas Pemberdayaan Perempuan dan Perlindungan Anak.

Efthimiou, K. \& Psoma, M. (2012). “Lewinshn's Cognitive Behavioral Group Therapy Course for Depression: Structure, Application and Efficacy". Journal Encephalos 49. Page 60-66, 2012.

Hadiati, M. (2001). "Kekerasan Dalam Rumah Tangga dalam Perspektif Hukum Pidana". Jurnal Perspektif. Volume VI No.2 Tahun 2001 Edisi April.

Hotifah, Y. (2011). "Dinamika Psikologis Perempuan Korban Kekerasan Dalam
Rumah Tangga". Jurnal PERSONIFIKASI.

Vol.2, No.1, Mei 2011.

Judiari, J. (2013). "Intervensi Psikologis pada Pemeriksaan KDRT (Kekerasan Dalam Rumah Tangga) Dalam PPA (Perlindungan Perempuan dan Anak) di Polresta Malang”. Jurnal Psikologi Islam (JPI). Volume 10. Nomor 1, Tahun 2013.

Komisi Nasional Anti Kekerasan Terhadap Perempuan (Komnas Perempuan). (2021). Perempuan Dalam Himpitan Pandemi: Lonjakan Kekerasan Seksual, Kekerasan Siber, Perkawinan Anak, dan Keterbatasan Penanganan di Tengah Covid-19. Jakarta: Catahu 2021 - Catatan Tahunan Kekerasan Terhadap Perempuan Tahun 2020, Diterbitkan tanggal 5 Maret

2021.

Krishnada, J. \& Taha, S. H. (2020). "Domestic Violence Through the Windows of The Covid19 Lockdown: A Public Crisis Embodied/ Exposed in the Private/ Domestic Sphere". Pluto Journal: Journal of Global Faultines. June - August 2020 Vol. 7, No.1 (June August 2020), pp. 46

-58 .

McLaren, H. J., Wong, K. R., Nguyen, K. N., Mahamadachchi, K. N. D. (2020). "Covid- 19 and Women's Triple Burden: Vignettes From Sri Lanka, Malaysia, Vietnam and Australia". Social Science Journal. 2020, 9, 87.

Nadia, F. A. (2018). Pemenuhan Hak-hak Perempuan Korban Kekerasan Dalam Rumah Tangga Perspektif Feminisme (Studi di Pusat Pelayanan Terpadu Pemberdayaan Perempuan dan Anak (P2TP2A) Kabupaten malang. Malang: Universitas Islam Negeri Maulana Malik Ibrahim Malang.

Nanthini, S. \& Nair, T. (2020). "Covid-19 and the Impacts on Women". NTS Insight. No. IN2005, July 2020.

Undang-undang Republik Indonesia. (2004). Undang-undang Nomor 23 Tahun 2004 Tentang Penghapusan Kekerasan Dalam Rumah Tangga. Disahkan di Jakarta pada Tanggal 22 September 2004 Oleh Presiden Republik Indonesia.

Walker, L. E. A. (2009). The Battered Woman Syndrome: Third Edition. New York: Springer Publishing Company.

World Health Organization (WHO). (2020). Gender and Covid-19: Advocacy Brief. World Health Organization (2020). 